\author{
ANDRZEJ KARAŚ \\ ORCID: 0000-0002-0028-0706
}

DOI: 10.4467/20801335PBW.21.015.13572

\title{
Modelowanie operacji informacyjnych z wykorzystaniem teorii sterowania refleksyjnego ${ }^{1}$
}

Słowa Heraklita z Efezu, że jedyną stałą rzeczą w życiu jest zmiana, doskonale oddają rzeczywistość, w jakiej żyjemy. Zmiany środowiska, układu sił politycznych, postęp w nauce, zmiany kulturalne czy technologiczne są możliwe do zaobserwowania w dłuższych odstępach czasu. Niezmienne pozostało niestety istnienie konfliktów między ludźmi oraz między innymi podmiotami. Dzięki osiągnięciom nauki i techniki zmieniają się jedynie formy tych konfliktów. Ponadto żyjemy w czasach, w których te zmiany przybierają na intensywności. Informacja zawsze odgrywała ważną rolę w sytuacjach konfliktowych, jednak w dzisiejszych czasach ta zależność jest jeszcze bardziej widoczna. Jako główną przyczynę tej sytuacji należy wskazać informatyzację oraz technokratyzację praktycznie każdej dziedziny życia. Powoduje to, że całe społeczeństwa, firmy czy instytucje państwowe są coraz bardziej uzależniane od potrzeby przetwarzania oraz wymiany informacji. Na bazie tych doświadczeń oraz osiągnięć nauki i techniki powstała koncepcja wojny informacyjnej oraz operacji informacyjnej jako nowoczesnych form rozstrzygania sytuacji konfliktowych.

Dzięki technologii zastosowanie operacji informacyjnych w konfliktach zbrojnych czy działań informacyjnych w konfliktach niemilitarnych, np. biznesie, stało się o wiele prostsze. Powszechny dostęp do internetu spowodował, że wpływanie na opinię całych społeczeństw nigdy nie było tak łatwe. Każdy może opublikować w krótkim czasie wiadomość dla odbiorców z całego świata, czego nie może zaoferować telewizja czy prasa. Skalę problemu pokazuje liczba tak zwanych fake newsów w mediach. Nie bez powodu współczesne społeczeństwa są nazywane społeczeństwami informacyjnymi. Obecnie odpowiednio dobrane słowa ludzi, którzy cieszą się dużym

Fragment pracy magisterskiej pt. Modelowanie operacji informacyjnych $z$ wykorzystaniem teorii sterowania refleksyjnego (Wojskowa Akademia Techniczna, Wydział Cybernetyki). Autor wykorzystał fragmenty rozdziału 1., Wstęp oraz w całości podrozdziały od 3.3. do 4.2. włącznie. 
autorytetem w społeczeństwie, mogą równać się dawnej sile militarnej wywierającej wpływ na jednostki oraz rządy. Operacje informacyjne były wykorzystywane w walce od zawsze, do dziś przesądzają one o klęsce lub wygranej na konwencjonalnym polu walki. Teoretycy wojenni oraz historycy porównują zjawisko wojny informacyjnej do wynalezienia czołgu oraz bomby atomowej i ich wpływu odpowiednio na pierwszą oraz drugą wojnę światową. Dowódcy są zgodni także co do wzrostu znaczenia operacji informacyjnych w przyszłych konfliktach. Pisze o tym także Gabriel Nowacki: Coraz częściej w sferze pozamilitarnych form walki szukać się będzie możliwości obrony lub ataku, uzyskania równowagi lub przewagi i być może decydujacych rozstrzygnięć ${ }^{2}$.

\section{Pojęcie refleksji}

Koncepcja sterowania refleksyjnego opiera się na pojęciu refleksja. Podobnie do informacji, refleksja ma wiele definicji. Każdy z autorów podaje wykładnię refleksji w zależności od swoich potrzeb oraz obszaru badań. Słownik języka polskiego objaśnia ten termin jako: (...) głębsze zastanowienie się nad czymś, wywołane silnym przeżyciem. Jednym z filozoficznych wyjaśnień podanych przez słownik jest: (...) zwrócenie się podmiotu myślacego ku własnej aktywności $i^{3}$. Refleksja może być rozumiana zwyczajowo jako ludzka umiejętność do zajmowania stanowiska obserwatora w stosunku do własnych myśli, przekonań oraz uczuć ${ }^{4}$ Ten termin może oznaczać także subiektywne uwzględnienie wiedzy oraz krytyczną analizę jej istoty. Przejawem tego jest na przykład samoaktualizacja ludzi, tzn. poprawianie swoich działań na podstawie popełnionych błędów ${ }^{5}$. Może to być również wyciąganie nowych wniosków na podstawie dotychczasowej wiedzy. Dzięki refleksji w ludzkich umysłach istnieje odwzorowanie, tzw. obraz realnej rzeczywistości. Ta rzeczywistość jest tworzona przez obiekty zarówno materialne, np. przedmioty, jak i niematerialne, np. słowa. Rzeczywistość wytworzona w umyśle człowieka w procesie refleksji jest nazywana rzeczywistością refleksyjną.

Należy wyróżnić dwa rodzaje refleksji. Refleksją pierwszego rodzaju lub inaczej samorefleksją jest nazywany proces analizy własnych myśli, przekonań oraz zasad działania. Produktem tego procesu jest obraz rzeczywistości w umyśle podmiotu. Refleksja drugiego rodzaju przejawia się przez umiejętność podmiotu do tworzenia wyobrażeń na temat obrazów rzeczywistości innych podmiotów. Obejmuje ona przeświadczenie

2 G. Nowacki, Wspótczesne poglądy na prowadzenie walki informacyjnej. Studium teoretyczne, Warszawa 2001.

3 Słownik języka polskiego, https://sjp.pwn.pl/szukaj/refleksja.html [dostęp: 8 IV 2019].

4 V.A. Lefebvre, Sketch of Reflexive Game Theory, Irvine 1998.

5 D.A. Novikov, A.G. Chkhartishvili, Mathematical Models of Informational and Strategic Reflexion: a Survey, „Advances in Systems Science and Application” 2014, nr 3, s. 254-278. 
danego podmiotu na temat przekonań, zasad działania oraz samorefleksji innych podmiotów ${ }^{6}$.

Należy dodać, że ten proces jest nieskończony z powodu swojej rekurencyjnej ${ }^{7}$ istoty, tzn. jedno przekonanie tworzy kolejne przez refleksję. Pojęcie „refleksja” uogólnił oraz rozszerzył Vladimir A. Lefebvre ${ }^{9}$, rosyjski psycholog i matematyk.

Dzięki rekurencyjnemu charakterowi zjawiska oraz uogólnieniu wprowadzonemu przez autora teorii można wyróżnić hierarchię rzeczywistości, którą obrazuje rys. 1.

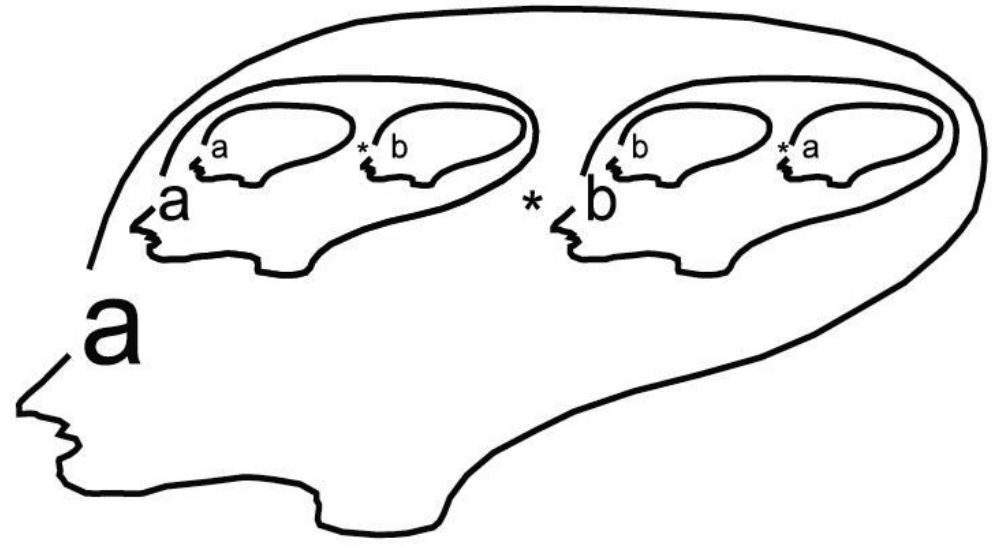

Rys. 1. Hierarchia rzeczywistości jako wynik procesu refleksji.

Źródło: V.A. Lefebvre, Sketch of Reflexive Game Theory, Irvine 1998.

Największa z głów odpowiada podmiotowi (agentowi) refleksyjnemu, tzn. osobie dokonującej refleksji - (a). Dwie zagnieżdżone głowy przedstawiają „obraz siebie” (a) oraz „obraz innego agenta” (b) z punktu widzenia zewnętrznego obserwatora. Dla agenta (a) pełnią one rolę „prawdziwy ja” oraz „prawdziwy inny”. Cztery zagnieżdżone głowy przedstawiają obrazy rzeczywistości z perspektywy agenta (a) - lewa para twarzy oraz z perspektywy agenta (b) - prawa para twarzy. Hierarchię rzeczywistości można przedstawić także w postaci drzewa, które Lefebvre nazywa strukturą refleksyjną (rys. 2) ${ }^{10}$.

6 Tamże; M. Wojnowski, „Zarzadzanie refleksyjne” jako paradygmat rosyjskich operacji informacyjno-psychologicznych w XXI w., „Przegląd Bezpieczeństwa Wewnętrznego” 2015, nr 12, http://cejsh.icm.edu.pl/cejsh/element/bwmeta1.element.desklight-ee571f3e-2942-46ce-9e19-af8e970c6f7a [dostęp: 30 III 2019].

7 Rekurencyjny - w matematyce, logice, programowaniu: dający się obliczyć, wyrazić za pomocą wielkości uprzednio znanych, https://sjp.pl/rekurencyjny (przyp. red).

8 R. Kasprzyk, The Essence of Reflexive Control and Diffusion of Information in the Context of Information Environment Security, w: Internetional Conference in Intelligent Systems in Production Engineering, and Maintenance. ISPEM 2018. Advances in Intelligent Systems and Computing, t. 835, A. Burduk i in., A. Tubis (red.), Cham 2018, s. 720-728.

9 V.A. Lefebvre, Sketch of Reflexive Game Theory...

10 Tamże. 


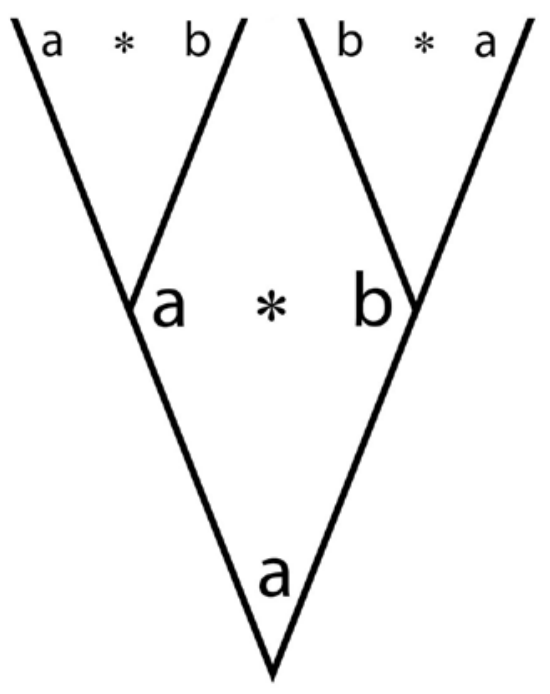

Rys. 2. Struktura refleksyjna.

Źródło: V.A. Lefebvre, Sketch of Reflexive Game Theory, Irvine 1998.

Korzeń drzewa przedstawionego powyżej odpowiada działaniom agentów. Węzły na drugim poziomie drzewa przedstawiają rzeczywistość widzianą przez agenta. Węzły na trzecim poziomie drzewa reprezentują rzeczywistość dla pierwszego oraz drugiego agenta z punktu widzenia pierwszego agenta ${ }^{11}$. Hierarchia rzeczywistości może zostać uogólniona do $n$ poziomowej hierarchii, co Lefebvre pokazuje w swoim artykule. Jak można zauważyć na powyższych rysunkach, rzeczywistości wytworzone przez agentów są jedynie subiektywnymi reprezentacjami realnej rzeczywistości ${ }^{12}$.

\section{Refleksja a sterowanie}

Zgodnie ze słowami Mariana Mazura sterowaniu zawsze towarzyszy dążenie do pewnego ustalonego celu ${ }^{13}$. Może być ono także definiowane jako (...) celowy wplyw wywierany na kontrolowany system $w$ celu zapewnienia jego wymaganego zachowania ${ }^{14}$. Zgodnie z teorią sterowania, wyróżniamy system sterujący oraz sterowany, które są połączone wzajemnie torami sterowniczymi. Możliwe jest także uwzględnienie zewnętrznych zakłóceń oddziałujących na oba systemy ${ }^{15}$. Opisywaną sytuację ilustruje rys. 3 .

\footnotetext{
11 Tamże.

12 R. Kasprzyk, The Essence of Reflexive Control...

13 M. Mazur, Jakościowa teoria informacji, Warszawa 1970.

14 D.A. Novikov, A.G. Chkhartishvili, Mathematical Models of Informational..., s. 255.

15 M. Mazur, Cybernetyczna teoria układów samodzielnych, Warszawa 1966.
} 


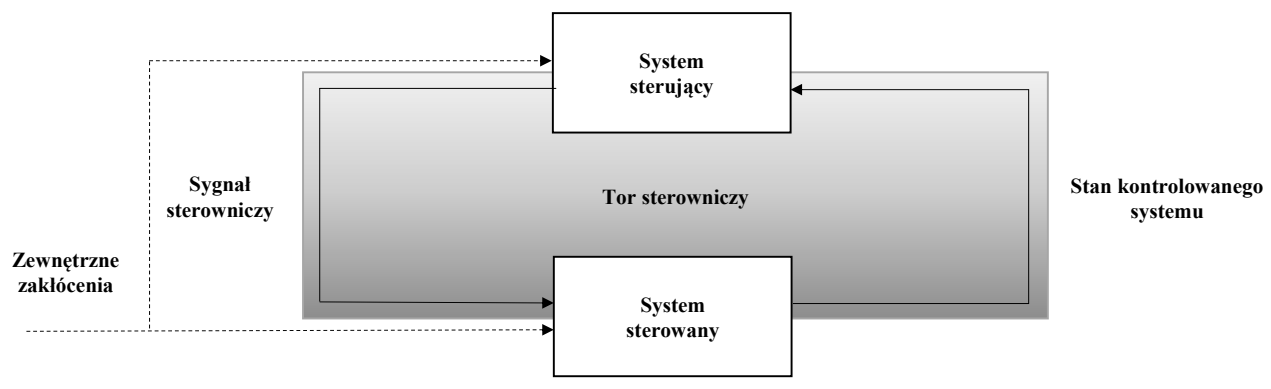

Rys. 3. System sterowany i sterujący jako układ cybernetyczny.

Źródło: D.A. Novikov, A.G. Chkhartishvili, Mathematical Models of Informational and Strategic Reflexion: a Survey, „Advances in Systems Science and Application” 2014, nr 3, s. 254-278.

Najważniejszą funkcją systemu sterującego jest wybór oraz wykonanie odpowiedniej akcji w celu wymuszenia na systemie kontrolowanym pożądanego działania. Trudnością dla wspomnianego systemu kontrolującego jest wpływ zewnętrznych zakłóceń na wybór akcji. Najważniejszym elementem jest tor sterowniczy, który pełni funkcję środowiska umożliwiającego wzajemne oddziaływanie obu systemów. Dzięki temu może zaistnieć sprzężenie zwrotne między systemem sterowanym a systemem sterującym ${ }^{16}$.

Wspomniane sprzężenie zwrotne może być rozumiane jako proces refleksji, tzn. budowanie obrazu systemu sterowanego przez system sterujący. Jest to pierwsze powiązanie między procesem sterowania a procesem refleksji. Drugie powiązanie opiera się na tym, że każdy z aktywnych systemów, tj. ludzie bądź dana zbiorowość, jest zdolny do wykonania refleksji pierwszego stopnia ${ }^{17}$. Tylko takie systemy będą rozpatrywane w dalszej części tekstu.

W celu przewidywania zachowania oraz odpowiedzi podmiotu kontrolowanego jest potrzebny jego model. Jest on rozumiany jako obraz danego systemu, który może zostać przedstawiony w postaci schematu, fizycznego obiektu lub istnieć jedynie w świadomości podmiotu kontrolującego. Sam proces modelowania, tj. tworzenia obrazu danego systemu, może być rozpatrywany jako proces refleksji. $Z$ tego wynika trzecie powiązanie między sterowaniem a refleksją rozumiane jako umiejętność podmiotu sterującego oraz sterowanego przeprowadzenia procesu refleksji w stosunku do innych podmiotów czy obiektów ${ }^{18}$.

Decydującym czynnikiem wykorzystywanym w sterowaniu refleksyjnym jest możliwość kontrolowania samego procesu refleksji oraz jej wyników. Ta relacja stwarza możliwość informacyjnej oraz refleksyjnej kontroli (sterowania refleksyjnego) ${ }^{19}$.

\footnotetext{
16 D.A. Novikov, A.G. Chkhartishvili, Mathematical Models of Informational...

17 Tamże.

18 Tamże.

19 Tamże.
} 


\section{Pojęcie sterowania refleksyjnego}

Była już mowa o koncepcji wojny informacyjnej oraz operacji informacyjnej (te terminy będą stosowane zamiennie). Jednym $\mathrm{z}$ niemilitarnych sposobów prowadzenia operacji informacyjnych jest sterowanie refleksyjne. To zjawisko jest znane także pod nazwą zarządzania refleksyjnego. Autorem tej teorii jest wspomniany Lefebvre. Głównym celem sterowania refleksyjnego jest wpłynięcie na nieświadomą jednostkę lub daną zbiorowość tak, aby dokonała pewnego, z góry założonego przez atakującego, czynu.

Najważniejszą „bronią” wykorzystywaną w procesie zarządzania refleksyjnego jest odpowiednio spreparowana informacja. Obiektem tego procesu jest umysł człowieka jego przekonania oraz poglądy. Bardzo trafnie ujął to Michał Wojnowski: Mimo uptywu stuleci, obiektami manipulacji nadal pozostają: świadomość, emocje i zachowania ludzi. Ciagłemu doskonaleniu ulegaja natomiast sposoby i narzędzia wywierania wpływu na zbiorowości ludzkie, do czego przyczynia się intensywny rozwój nauki i techniki $i^{20}$. Cel jest realizowany za pomocą technik manipulacji oraz sterowania społeczeństwem.

Jak napisano wcześniej, każdy podmiot tworzy własny obraz rzeczywistości w procesie refleksji. Pozostające poza świadomością podmiotu oddziaływanie agresora na jego myśli, przekonania oraz na sam proces refleksji będzie pośrednio wpływało na proces decyzyjny tego podmiotu. Tym samym późniejsze działania podmiotu powinny być zgodne z założeniami agresora.

Według Lefebvre'a zarządzanie refleksyjne można realizować przez:

- kreowanie oraz przekazywanie fałszywego obrazu sytuacji;

- przedstawienie przeciwnikowi uwiarygodnionego planu własnych działań;

- zobrazowanie oponentowi wielu nieprawdziwych celów.

Inne techniki wykorzystywane $\mathrm{w}$ procesie zarządzania refleksyjnego Wojnowski opisuje szerzej w swoim artykule ${ }^{21}$.

Zastosowanie wyżej wymienionych technik, z wykorzystaniem takich kanałów dystrybucji informacji, jak media społecznościowe lub środki masowego przekazu, powinno umożliwić skuteczne manipulowanie percepcją jednostek czy całych społeczności. Na potwierdzenie tej tezy należy przedstawić sposób, w jaki ludzie pozyskują oraz weryfikują wiarygodność informacji ${ }^{22}$. Niestety w dzisiejszych czasach większość informacji jest przyjmowana bezkrytycznie, co może być wykorzystane do niezauważalnego wprowadzenia informacji do świadomości człowieka ${ }^{23}$.

\footnotetext{
20 M. Wojnowski, „Zarządzanie refleksyjne” jako paradygmat..., s. 11.

21 Tamże.

22 R. Kasprzyk, The Essence of Reflexive Control...

${ }^{23}$ M. Wojnowski, „Zarzadzanie refleksyjne” jako paradygmat...
} 


\section{Sterowanie refleksyjne jako model sytuacji konfliktowych}

Teorię sterowania refleksyjnego należy rozpatrywać także w kontekście modelowania sytuacji konfliktowych, co zauważył sam autor teorii. To podejście jest alternatywną formą modelowania sytuacji strategicznych w przypadku braku pełnej informacji. Tym zagadnieniem zajmuje się teoria gier refleksyjnych zaproponowana przez Lefebvre'a. Wspomniane podejście różni się także od teorii zachowania zbiorowego, która uznaje, że każdy z graczy prowadzi własny proces decyzyjny, przy równoczesnej niewiedzy na temat zachowań oraz informacji posiadanych przez przeciwników.

Metoda sterowania refleksyjnego wydaje się bardziej adekwatna do opisu sytuacji strategicznych niż modele budowane za pomocą klasycznej teorii gier. Żaden z graczy w rzeczywistości nie ma takich samych przekonań, zasad działania ani informacji o stanie danej gry. Dlatego należy przyjąć, że żaden z nich nie odbiera sytuacji konfliktowej obiektywnie. Różnice przejawiają się w postrzeganiu zasad, celów, ról oraz świadomości poszczególnych graczy ${ }^{24}$.

Sterowanie refleksyjne wykorzystuje zjawisko refleksji także do budowania wyobrażenia o innych graczach oraz ich poczynaniach - hierarchii przekonań. Ta technika bazuje na modelu refleksyjnym stworzonym na podstawie informacji posiadanych przez gracza, stąd tak ważne są działania wywiadowcze w rzeczywistym świecie. Pozwala lepiej przewidzieć poczynania przeciwników oraz wydaje się bardziej adekwatna niż probabilistyczne ${ }^{25}$ oszacowania. Dodatkowo daje możliwość przedstawienia, jak dany gracz postrzega siebie oraz swoich przeciwników, czego nie zapewniają inne modele. Potwierdzają to słowa autora teorii: (...) model podmiotu powinien odzwierciedlać nie tylko sferę jego zachowania, lecz także jego zdolność do pojmowania samego siebie i drugich podmiotów, włączając i te, które próbuja uzyskać kontrolę nad jego działaniem ${ }^{26}$. Wiedza o tym, jak rozumuje przeciwnik, uzyskana na podstawie modelu refleksyjnego daje dużą przewagę na każdym polu. Lefebvre twierdził, że każda sytuacja konfliktowa toczy się w trzech sferach:

- sferze fizycznej - przez wszelakiego rodzaju starcia oraz interakcje;

- sferze technicznej - dzięki przeciwstawnym systemom informacyjno-kierowniczym;

- sferze kognitywnejej, w której potyczka dotyczy procesów mających wpływ na decyzje uczestników konfliktu ${ }^{28}$.

Poprawne odwzorowanie danej sytuacji konfliktowej jest najważniejszym czynnikiem decydującym o zwycięstwie. $Z$ tego powodu sterowanie refleksyjne skupia się

24 D.A. Novikov, A.G. Chkhartishvili, Mathematical Models of Informational...

${ }_{25}$ Probabilistyka - dział matematyki zajmujący się badaniem prawidłowości występujących w zdarzeniach losowych, https://sjp.pwn.pl/slowniki/probabilistyczny.html (przyp. red.).

26 M. Wojnowski, „Zarządzanie refleksyjne” jako paradygmat..., s. 20.

27 Poznawczej (przyp. red.).

28 Zob. M. Wojnowski, „Zarzadzanie refleksyjne” jako paradygmat... 
na ingerencji w świadomość oraz poglądy przeciwnika w celu zmiany jego obrazu myślenia. Takie działania wpływają na proces decyzyjny oponenta.

Tworzenie modelu refleksyjnego jednostki lub danej społeczności bazuje na portretach psychologicznych. Jednak ten model jest znacznie szerszym pojęciem niż portret psychologiczny ${ }^{29}$. Zgodnie z wcześniejszymi rozważaniami powinien on zawierać odwzorowanie rozumowania oraz samoświadomości podmiotu, wraz z opisem jego potencjalnych zachowań w danej sytuacji.

Co więcej, ta teoria znajduje zastosowanie także na innych polach. Potwierdzają, słowa Wojnowskiego: Teoria ta może też znajdować zastosowanie $w$ tworzeniu tzw. modeli refleksyjnych przestępców, terrorystów, a nawet całych grup i organizacji ${ }^{30}$. Wspomniany autor podkreśla także wkład Mariana Mazura w teorię tworzenia profili psychologicznych w postaci układów samodzielnych, która służy do typowania przywódców organizacji przestępczych ${ }^{31}$.

\section{Refleksja informacyjna a strategiczna}

Klasyfikacja refleksji ze względu na stopień świadomości podmiotu została opisana wcześniej. Istnieje jednak jeszcze jeden dość istotny podział: ze względu na cel lub wynik refleksji.

$\mathrm{Na}$ proces oraz wyniki refleksji informacyjnej składają się dane na temat parametrów niepewnych co do wartości, posiadane przez dany podmiot oraz jego przeciwników. Natomiast wyniki refleksji strategicznej zawierają informacje o zasadach decyzyjnych stosowanych przez przeciwników dzięki zbudowanej przez siebie świadomości - na podstawie strategii informacyjnej. Należy dodać, że obie te techniki znajdują zastosowanie w sytuacji, gdy mamy do czynienia z niepełną lub niewystarczającą informacją ${ }^{32}$.

\section{Szkielet sterowania refleksyjnego}

Na podstawie informacji przedstawionych wcześniej można stwierdzić, że proces sterowania refleksyjnego pod wieloma względami jest podobny do procesu sterowania. Z tego względu może zostać opisany za pomocą definicji oraz schematów procesu sterowania. W celu uproszczenia opisu zagadnienia w procesie sterowania refleksyjnego zostaną wyróżnione dwa systemy. Są nimi: podmiot sterujący (system sterujący) oraz podmiot sterowany (system sterowany), które można przedstawić za pomocą schematu (rys. 4). Zadaniem systemu kontrolującego jest całkowite przejęcie kontroli

\footnotetext{
29 Tamże.

30 Tamże, s. 35.

31 Tamże.

32 D.A. Novikov, A.G. Chkhartishvili, Mathematical Models of Informational...
} 
lub wpłynięcie na proces decyzyjny systemu kontrolowanego. W tym celu podmiot kontrolujący musi zbudować z posiadanych przez siebie informacji model podmiotu kontrolowanego. Następnie na podstawie modelu jest preparowana odpowiednia informacja, która ma wpłynąć na przekonania bądź zasady działania obiektu ${ }^{33}$. Po czym jest ona przesyłana do obiektu kontrolowanego przez specjalnie wyselekcjonowany kanał komunikacji (o czym pisze Wojnowski oraz co pokazuje model rozprzestrzeniania się informacji $\left.i^{34}\right)$.

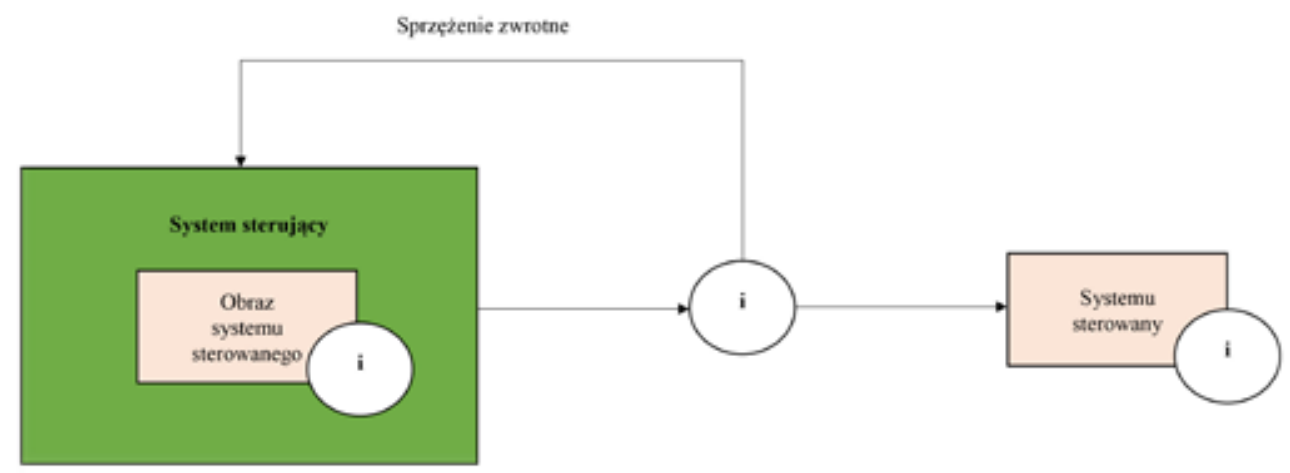

Rys. 4. Tworzenie obrazu systemu sterującego w procesie refleksji.

Źródło: Opracowanie własne na podstawie: R. Kasprzyk, The Essence of Reflexive Control and Diffusion of Information in the Context of Information Environment Security, w: Internetional Conference in Intelligent Systems in Production Engineering, and Maintenance. ISPEM 2018. Advances in Intelligent Systems and Computing, t. 835, A. Burduk, E. Chlebus, T. Nowakowski, A. Tubis (red.), Cham 2018, s. 720-728.

Nieodpowiednio dobrany kanał do transmisji informacji może prowadzić do skutków przeciwnych niż zamierzone. Ostatnim krokiem w procesie sterowania refleksyjnego jest pobranie nowej informacji o obiekcie sterowanym przez podmiot sterujący. Ten krok jest nazywany sprzężeniem zwrotnym lub właśnie refleksją. Każda nowa informacja rozbudowuje model podmiotu sterowanego, który posiada podmiot sterujący. Kilkakrotne powtórzenie wymienionych kroków zazwyczaj prowadzi do wywarcia zamierzonego wpływu na podmiot sterowany ${ }^{35}$.

Liczba podmiotów sterujących oraz kontrolowanych jest zazwyczaj większa w przypadkach praktycznych. Co ważniejsze, każdy z nich pełni obie te funkcje naraz, tzn. stara się zmienić świadomość swoich przeciwników oraz jest poddany takim działaniom ze strony swoich oponentów. Zasadniczym problemem przy modelowaniu

33 R. Kasprzyk, The Essence of Reflexive Control...

${ }^{34}$ M. Wojnowski, „Zarzadzanie refleksyjne” jako paradygmat...; A.P. Mikhailov, N.A. Marevtseva, Models of Information Warfare, "Mathematical Models and Computer Simulations” 2012, nr 3, s. 251-259.

35 R. Kasprzyk, The Essence of Reflexive Control... 
procesu sterowania refleksyjnego w mediach społecznościowych jest zrozumienie procesu rozprzestrzeniania się (dyfuzji) informacji w systemach sieciowych ${ }^{36}$.

\section{Bazowy model sterowania refleksyjnego}

Przed zdefiniowaniem bazowego modelu gry refleksyjnej należy omówić pojęcie rów nowaga Nasha. Oznacza ono, że gracz po określeniu własnej strategii i po wybraniu strategii przez jego oponentów nie zwiększy swojej wypłaty przez zmianę swojego planu działania. Można to przedstawić za pomocą poniższej nierówności, która musi być spełniona dla każdego z $n$ graczy:

$$
u_{i}\left(s_{i}, \theta_{-i}\right)>u_{i}\left(s_{i}^{\prime}, \theta_{-i}\right)
$$

gdzie:

$\mathrm{i}=1, \ldots, \mathrm{n}$.

Za pomocą równowagi Nasha można wyznaczyć najlepsze rozwiązania (równowagę) dla danej gry ${ }^{37}$.

\section{Składowe opisu modelu}

Model teoriogrowy lub zbiorowego zachowania może być rozpatrywany na trzech poziomach:

- fenomenologicznym - opisuje on działanie systemu za pomocą odpowiednio zbudowanego modelu gry;

- predykcyjnym - jest równoznaczny z przewidywaniem zachowania się systemu, tzn. ustalaniem się równowagi;

- normatywnym - opisuje proces kontroli systemu, tzn. osiąganie wcześniej założonej równowagi przez odpowiednie dobranie parametrów opisujących system $^{38}$.

Biorąc pod uwagę refleksję informacyjną oraz strategiczną, można wyróżnić trzy elementy składające się na wcześniej wymienione poziomy opisu modelu. W przypadku refleksji informacyjnej są nimi: struktura świadomości (ang. awareness structure), równowaga informacyjna oraz sterowanie informacyjne. Natomiast refleksję

${ }^{36}$ R. Kasprzyk, Diffusion in Networks, „Journal of Telecommunications and Information Technology" 2012, nr 2, s. 99-106; tenże, Modele ewolucji systemów złożonych i metody badania ich charakterystyk dla potrzeb komputerowej identyfikacji potencjalnych sytuacji kryzysowych, 2012 r., Wojskowa Akademia Techniczna, praca doktorska.

37 J. Watson, Wprowadzenie do teorii gier, Warszawa 2011.

38 D.A. Novikov, A.G. Chkhartishvili, Mathematical Models of Informational... 
strategiczną można opisać za pomocą: struktury refleksyjnej (ang. reflexive structure), równowagi refleksyjnej oraz sterowania refleksyjnego ${ }^{39}$.

\section{Model gier refleksyjnych}

Zgodnie z wcześniejszymi rozważaniami idea sterowania refleksyjnego opiera się na budowaniu przez każdego z graczy subiektywnych obrazów rzeczywistości. Ten proces może zostać opisany za pomocą modelu zwanego grą refleksyjną $\Gamma_{I}$, w którym to pojęcie jest definiowane jako następująca krotka ${ }^{40}$ :

$$
\Gamma_{I}=\left\{N,\left(X_{i}\right)_{i \in N}, f_{i}(\cdot)_{i \in N}, I\right\}
$$

gdzie:

$\mathrm{N}=\{1,2, \ldots, \mathrm{n}\}-$ zbiór graczy (agentów);

$X_{i}$ - zbiór możliwych akcji gracza $i$;

$f_{i}(\cdot): \Theta \times X^{\prime} \rightarrow \mathrm{R}^{1}$ - funkcja wypłaty gracza $i$, jako iloczyn kartezjański na zbiorze wartości parametrów $\Theta$ (nieokreślonych jednoznacznie co do wartości) oraz $X^{\prime}$ zbiorze akcji;

$I$ - struktura świadomości ${ }^{41}$.

Szerszego wyjaśnienia wymaga struktura świadomości. Załóżmy, że nieokreślony (co do wartości) parametr będzie oznaczany symbolem $\theta$, dodatkowo $\theta \in \Theta$. Przez symbol $\Theta$ jest rozumiany zbiór wspólnej wiedzy dla każdego z graczy. Zawiera on wszystkie możliwe wartości parametrów $\theta$. Struktura świadomości gracza $i$ zawiera następujące elementy:

- przekonanie gracza $i$ na temat wartości parametru; jest ono oznaczane przez $\theta_{i}$, gdzie $\theta \in \Theta$;

- przekonanie gracza $i$ o przekonaniach innego z graczy na temat wartości parametru $\theta$; jest ono oznaczane przez $\theta_{i j}$, gdzie $\theta_{i j} \in \Theta$ oraz $j \in N$;

- przekonanie gracza $i$ o przekonaniach gracza $j$ oraz o przekonaniach innego z graczy na temat wartości parametru $\theta$; jest ono oznaczane przez $\theta_{i j k}$, gdzie $\theta_{i j k}$ $\in \Theta$ oraz $k \in N$. Jak można zauważyć ten proces może być rozwijany w nieskończonośćc ${ }^{42}$.

Należy dodać, że struktury świadomości wszystkich graczy składają się na strukturę świadomości danej gry. Zaznaczenia wymaga fakt, że żaden z graczy nie ma pełnej

\footnotetext{
39 Tamże.

40 Krotka - struktura danych będąca odzwierciedleniem matematycznej n-ki, tj. uporządkowanego ciągu wartości. Za: Wikipedia [dostęp: 26 III 2021] - przyp. red.

${ }^{41}$ D.A. Novikov, A.G. Chkhartishvili, Mathematical Models of Informational...

${ }^{42}$ Tamże.
} 
wiedzy składającej się na strukturę świadomości. Struktura świadomości jest nazywana także strukturą informacyjną lub hierarchią przekonań.

\section{Równowaga informacyjna a sterowanie informacyjne}

Novikov i Chkhartishvili wprowadzili w swoim artykule także pojęcie równowaga in for macyjna (ang. information equilibrium), które zawiera dane:

- o skończonej liczbie realnych graczy oraz graczy fantomowych, tzn. wyobrażeń na temat graczy w umysłach ich przeciwników;

- o tym, że dwóch agentów o identycznej strukturze świadomości podejmie taką samą decyzję lub akcję;

- o tym, że każdy z agentów dąży do maksymalizacji swojej wypłaty przez odpowiednio wybrane akcje ${ }^{43}$.

Należy dodać, że w tym celu gracze wykorzystują przekonania o innych graczach, podstawiając wyobrażenia o ich możliwych akcjach do swojej funkcji celu. Co więcej, świadomość na temat oponentów danego gracza będzie się zmieniać. Dzieje się tak dzięki połączeniu wiedzy o ich aktualnych działaniach oraz przekonań danego gracza na ich temat.

$\mathrm{Na}$ podstawie pojęcia równowagi informacyjnej została sformułowana definicja sterowania informacyjnego. Polega ono na odpowiednim manipulowaniu świadomością (w istocie strukturą świadomości) oponentów. Wynikiem tej manipulacji jest osiągnięcie pożądanej równowagi informacyjnej, która jest jednym z możliwych rozwiązań gry ${ }^{44}$. Innymi słowy, zmanipulowany gracz podejmie decyzje, które będą korzystne dla jego przeciwnika.

\section{Struktura, równowaga refleksyjna a sterowanie refleksyjne}

Alternatywną formą refleksji jest refleksja strategiczna, która może zostać opisana za pomocą struktury oraz równowagi refleksyjnej.

Istnieje wiele modeli refleksji strategicznej, jednak mogą one zostać uogólnione do modelu opisanego za pomocą poniższej funkcji celu:

$$
w_{i}\left(x_{-i}^{t}\right)=\arg \max _{y \in \mathcal{R}^{1}} F_{i}\left(y, x_{-i}^{t}\right)
$$

gdzie:

$w_{i}\left(x_{-i}^{t}\right)$ - funkcja wypłaty w zależności od akcji oponentów i-tego gracza w chwili $t$;

$y$ - akcja i-tego gracza;

$F_{i}$ - funkcja celu i-tego gracza ${ }^{45}$.

\footnotetext{
43 Tamże.

44 Tamże.

45 Tamże.
} 
Jak można zauważyć, decyzja oraz wypłata i-tego gracza nie zależy od poprzednich akcji graczy, jak ma to miejsce w teorii zbiorowego zachowania. Zależą one jedynie od subiektywnej oceny działań graczy na podstawie refleksji. Dlatego też Novikov i Chkhartishvili wprowadzili pojęcie refleksyjny podział zbioru graczy $\aleph$, dzielącego graczy na podstawie poziomu ich refleksji. Poniżej została przedstawiona definicja refleksyjnego podziału zbioru:

$$
\aleph=\left\{N_{0}, N_{1}, \ldots, N_{m}\right\}
$$

gdzie:

$N_{i}$ - zbiór graczy o poziomie refleksji $i, i=1, \ldots, m$, gdzie $m$ oznacza maksymalny poziom refleksji danego gracza ${ }^{46}$.

Należy dodać, że gracz o poziomie refleksji $i$ uznaje, że każdy z jego oponentów jest na poziomie refleksji co najmniej o jeden mniejszym, co obrazuje poniższy wzór:

$$
\aleph_{j k}=\left\{N_{0}, N_{1}, \ldots, N_{k-2}, N_{k-1} \cup N_{k} \cup \ldots \cup N_{m} \backslash\{\mathrm{j}\}, \mathrm{j} \in N_{k}\right\}
$$

gdzie:

$\aleph_{j k}$ - subiektywny podział zbioru gracza $j$ o poziomie refleksji $k$.

Takie założenie prowadzi do błędnej klasyfikacji oponentów o poziomie refleksji $k$ do zbioru o poziomie refleksji $k-1$. Autorzy przedstawili w swoim artykule także równania opisujące sposób wyboru akcji przez gracza o każdym poziomie refleksji ${ }^{47}$.

Strukturą refleksyjną jest nazywany zbiór subiektywnych, refleksyjnych podziałów zbioru wszystkich graczy. Należy dodać, że struktura świadomości może być jednoznacznie zdefiniowana także przez refleksyjny podział zbioru $\aleph$. Terminem równowaga refleksyjna jest opisywany zbiór akcji graczy, który tworzy najlepsze odpowiedzi na akcje oponentów, w odniesieniu do istniejącej struktury refleksyjnej w umysłach graczy. Ten zbiór może być przedstawiany także jako następujący wektor kolejnych akcji graczy $y^{48}$ :

$$
x^{*}(\aleph)=\left\{x k_{j}^{*}\left(\aleph_{j k}\right)\right\}_{j \in N_{k}, k=0, \ldots, m}
$$

\footnotetext{
46 Tamże.

47 Tamże.

48 Tamże.
} 
Trzeba nadmienić, że równowaga refleksyjna istnieje zawsze. Jednak akcje poszczególnych graczy nie zawsze są najlepszymi odpowiedziami. Wynika to $\mathrm{z}$ różnic $\mathrm{w}$ poziomie refleksji graczy, błędach w ich klasyfikacji oraz rozbieżności w wiedzy graczy ${ }^{49}$.

Definicja sterowania refleksyjnego może zostać sformułowana w analogii do definicji sterowania informacyjnego. Polega ono na odpowiedniej manipulacji refleksyjnymi podziałami zbioru graczy przez jednego z nich. Celem manipulacji jest zmiana zasad podejmowania decyzji przez oponentów, co w konsekwencji prowadzi do wykonania przez nich akcji zakładanej przez agresora. Oczywiście akcje wykonane przez oponentów różnią się od wyobrażeń danych graczy na ich temat. Stąd w każdej iteracji gracze modyfikują swoje wyobrażenia na temat innych graczy, przez co udoskonalają swoje przyszłe decyzje.

\section{Budowa modelu operacji informacyjnych $\mathrm{z}$ wykorzystaniem teorii sterowania refleksyjnego}

Większość modeli, które pozwalają na modelowanie wojny informacyjnej oraz operacji informacyjnych, ma swoje fundamenty w teorii gier. Szczególnym przykładem modelowania sytuacji strategicznych $\mathrm{z}$ niepełną wiedzą jej uczestników jest model hipergier. Alternatywnym podejściem jest wcześniej opisana koncepcja gry refleksyjnej zaproponowana przez Lefebvre'a. Połączenie pojęć refleksji informacyjnej, strategicznej, sterowania informacyjnego i refleksyjnego $\mathrm{z}$ teorią gier refleksyjnych pozwala na uzyskanie złożonego modelu, który umożliwia formalny opis operacji informacyjnych. Próba połączenia wspomnianych zagadnień zostanie przedstawiona poniżej.

\section{Przedstawienie ogólnego modelu}

Teoria sterowania wprowadza podział obiektów biorących udział w procesie sterowania na podmioty aktywne, tj. istoty ludzkie, grupy czy społeczności, oraz systemy pasywne np. urządzenia techniczne ${ }^{50}$. Model opisany poniżej będzie odnosił się jedynie do grupy podmiotów aktywnych.

Pierwszym z najważniejszych elementów modelu jest skończony zbiór graczy. W jego skład wchodzą wszystkie osoby bądź społeczności biorące udział w operacji informacyjnej. Kolejnym elementem są preferencje graczy reprezentowane przez wspomnianą wcześniej funkcję lub ogólnie zbiór funkcji wypłat, przypisany każdemu z graczy. Następną składową modelu jest zbiór możliwych akcji, które mogą być podjęte przez graczy. W szczególnym przypadku do opisu akcji, którymi dysponuje dany gracz, może być wymagane przedstawienie zbioru akcji i-tego gracza, innymi słowy nie wszyscy gracze muszą dysponować takimi samymi umiejętnościami. Jak wiadomo, decyzje

\footnotetext{
49 Tamże.

50 Tamże.
} 
strategiczne, które składają się na operacje informacyjne, są podejmowane na podstawie pozyskanych wcześniej informacji. Stąd model operacji informacyjnych powinien umożliwiać opis wiedzy każdego z graczy na temat kluczowych parametrów (dokładnie ich wartości). W teorii gier refleksyjnych ta składowa jest nazywana strukturą świadomości. Oczywiście dana operacja informacyjna nie składa się z jednej czynności albo akcji. Dlatego model powinien umożliwiać opis sekwencji czynności podejmowanych przez graczy. Składnikiem modelu, który rozszerza typowy model gier refleksyjnych, jest podział refleksyjny zbioru, a dokładnie jego podział przedstawiający wzajemną ocenę graczy co do poziomu swojej refleksji. Kolejnym ważnym rozszerzeniem modelu jest przedstawienie powiązania między strukturą świadomości, podziałem refleksyjnym zbioru a akcjami podejmowanymi przez graczy. W zależności od poziomu refleksji, postrzegania poziomu refleksji innych graczy oraz wiedzy na temat zasadniczych parametrów gry gracz podejmie inną decyzję. Warto także dodać, że zazwyczaj nie można wskazać dwóch graczy o takiej samej strukturze świadomości oraz podziale refleksyjnym. Potwierdza to przytoczone wcześniej stwierdzenia o istnieniu odrębnych subiektywnych rzeczywistości dla każdego z graczy. W przypadku gdy gracz jest pewny zdobytych informacji, modyfikuje swoją strukturę świadomości, co pozwala mu na podejmowanie lepszych decyzji. Gracze za pomocą akcji oddziałują na postrzeganie przeciwników w celu uzyskania przewagi. Należy także założyć, że niektóre akcje wchodzące w skład modelu opisują proces komunikacji między graczami. Ważnym czynnikiem jest również możliwość opisu częstości występowania akcji za pomocą prawdopodobieństwa. Połączenie struktury świadomości oraz podziału refleksyjnego będzie nazywane zunifikowaną strukturą świadomości. Natomiast gry opisane powyższym modelem będą nazywane macierzowymi grami refleksyjnymi. Ta gra jest definiowana przez następującą krotkę:

$$
\Gamma_{U}=\left\{N,\left(W_{i}\right)_{i \in N},\left(X_{i}\right)_{i \in N},\left(c_{i}\right)_{i \epsilon C},\left(A_{i}\right)_{i \epsilon N},\left(\aleph_{i}\right)_{i \epsilon N}\right\}
$$

gdzie:

$\mathrm{N}=\{1,2, \ldots, n\}-$ zbiór graczy (agentów);

$W_{i}=\left\{w_{i 1}, w_{i 2}, \ldots, w_{i k}\right\}$ - zbiór funkcji wypłat (preferencji) i-tego gracza, gdzie $\mathrm{w}_{i j}: \Theta \times \aleph \times X \rightarrow R^{1}$, tzn. j-ta funkcja wypłaty gracza $i$ jako iloczyn kartezjański na zbiorze wartości parametrów $\Theta$ (nieustalonych jednoznacznie co do wartości), pewnym podziale refleksyjnym $\aleph$ oraz zbiorze akcji $X$, a $k$ jest równe liczbie funkcji wypłat dla każdego z graczy;

$X_{i}=\left\{x_{i 1}, \ldots, x_{l}\right\}$ - zbiór możliwych akcji gracza $i$ będący podzbiorem zbioru $X$, gdzie $x_{i}-\mathrm{i}$-ta akcja;

$c_{i}=\left\langle\left\langle x_{1}, p_{1}\right\rangle,\left\langle x_{2}, p_{2}\right\rangle, \ldots,\left\langle x_{l}, p_{l}\right\rangle\right\rangle-i$-ta n-tka kolejnych akcji gracza wraz $\mathrm{z}$ ich prawdopodobieństwami wystąpienia (sekwencji czynności). Każda oryginalna n-tka będzie nazywana charakterem gracza, gdzie zbiór charakterów graczy będzie oznaczany symbolem C. Należy także dodać, że $L=|X|, l \leq L$ oraz $p_{i} \in<0,1>$; gdzie $L=|X|$ nazywamy mocą zbioru X;

$A_{i}=\left[a_{j k}\right]_{\mathrm{n} \times \mathrm{n}}-$ struktura świadomości i-tego gracza, gdzie:

$a_{w k}=\left\{\begin{array}{c}\theta_{j k} \in \Theta \text { jeżeli znany } \\ -w \text { przeciwnym wypadku }\end{array}\right.$ 
$\aleph_{i}=\left[n_{j k}\right]_{n \times n}$ - podział refleksyjny i-tego gracza, gdzie: $n_{j k} \in\{0,1, \ldots, m\} ; m$ to maksymalny poziom refleksji dostępny graczom, istnieje także ograniczenie takie, że $\forall_{n_{i i}, n_{i-} \in N} n_{i i}>n_{i-}$.

Analogicznie do równowagi refleksyjnej oraz sterowania refleksyjnego można zdefiniować zunifikowaną równowagę refleksyjną, która wyznacza najlepsze odpowiedzi (akcje) gracza w odniesieniu do konkretnej zunifikowanej struktury świadomości, tzn. połączenia konkretnej struktury świadomości $A_{i}$ oraz podziału refleksyjnego $\aleph_{i}$, danego gracza. Natomiast wpływ na struktury świadomości oraz podziały refleksyjne przeciwników w celu osiągnięcia założonej wcześniej zunifikowanej równowagi refleksyjnej może być nazywany zunifikowanym sterowaniem refleksyjnym.

\section{Opis gry p-Beauty Contest Game za pomoca modelu}

W podstawowej wersji tej gry każdy z jej uczestników wybiera liczbę z przedziału od 0 do 100. Następnie jest wyznaczana średnia z wyników, którą mnoży się przez współczynnik p. Gracz, który podał liczbę najbliższą wynikowi, wygrywa daną run$\mathrm{dę}^{51}$. W przypadku remisu gracze, którzy podali taką samą liczbę, uzyskują wygraną ex aequo. Na koniec każdej rundy gracze dowiadują się o wyniku oraz wyborach swoich przeciwników - jest to gra $\mathrm{z}$ tzw. pełną informacją. Istnieją także alternatywne wersje gry, tj. gry z niepełną wiadomością, w których gracze dowiadują się jedynie o swojej wygranej lub przegranej. Najbardziej skrajnym przykładem gry jest sytuacja, w której gracze nie otrzymują żadnej wiadomości na koniec rundy.

Aby opisać p-Beauty Contest Game za pomocą przedstawionego wcześniej modelu, należy zdefiniować wszystkie elementy składające się na krotkę $\Gamma_{U}$ ze wzoru macierzowych gier refleksyjnych. Pierwszym, najważniejszym elementem jest zbiór graczy (podmiotów) uczestniczących w grze $N$.

$$
N=\{1,2, \ldots, n\}
$$

gdzie:

$\mathrm{n}=6$.

W klasycznym podejściu funkcja wypłat wskazuje hierarchię rozwiązań danej gry, które w ocenie danego gracza są dla niego najlepsze. W przypadku gier z niepełną wiedzą oraz wielu ruchów, które dany gracz może wykonać, dobrym podejściem jest opis jego preferencji w odniesieniu do znanych parametrów. W przypadku p-Beauty Contest Game funkcja preferencji dla wszystkich racjonalnych graczy będzie wyglądać następująco:

${ }^{51}$ S. Skeath, J.A. Livingston, A Step Ahead? Experienced Play in the p-Beauty Game, https://ssrn.com/ abstract $=1680542$. 


$$
\mathrm{w}_{i}=\arg \min _{x_{i} \in<0,100>}\left|\frac{p \sum x_{i^{*}}}{n-p}-x_{i}\right|
$$

gdzie:

p - parametr, przez który jest mnożona średnia z liczb podanych przez graczy;

$x_{i}$ - wybór i-go gracza, który jest zarówno parametrem funkcji optymalizacji;

$\sum x_{i^{\star}}$ - suma wyborów przeciwników i-tego gracza wyznaczona na podstawie informacji posiadanych przez tego gracza;

$n$ - liczność zbioru graczy biorących udział w grze.

Na podstawie wzoru można zauważyć, że każdy gracz stara się dokonać wyboru, który zminimalizuje różnicę między średnią swoich oponentów a własnym wyborem. Takie podejście gwarantuje wygraną w danej rundzie. Należy przyjąć, że za każdą wygraną dany gracz otrzymuje jeden punkt.

Kolejnym elementem modelu wymagającym zdefiniowania są akcje, które mogą zostać podjęte przez graczy. Zgodnie z założeniami ogólnego modelu gracz nie musi dysponować wszystkimi dostępnymi akcjami.

Poniżej zostaną wymienione wszystkie akcje. Będą one unikalnie definiowane przez numer akcji:

- wybór liczby - numer akcji 1;

- wykonanie refleksji - numer akcji 2;

- poprawna podpowiedź co do swojego wyboru - numer akcji 3;

- niepoprawna podpowiedź co do swojego wyboru - numer akcji 4;

- podglądanie wyborów innych graczy - numer akcji 5;

- zaniżanie wyniku gry - numer akcji 6;

- zawyżanie wyniku gry - numer akcji 7.

Następnie zostanie zaprezentowany opis zbiorów akcji dostępnych dla graczy:

$X_{1}=\{1,2,5\}$

$X_{2}=\{1,6\}$;

$X_{3}=\{1,7\}$;

$X_{4}=\{1,2,3\}$;

$X_{5}=\{1,2,4\}$;

$X_{6}=\{1,2\}$.

Jak można zauważyć, każdy z powyższych graczy ma inny zbiór akcji, stąd należy zdefiniować tyle samo sekwencji czynności, tzn. charakterów graczy.

$$
\begin{aligned}
& c_{1}=\langle\langle 2 ; 1\rangle,\langle 6 ; 1\rangle,\langle 2 ; 1\rangle,\langle 1 ; 1\rangle\rangle ; \\
& c_{2}=\langle\langle 7 ; 0.5\rangle,\langle 1 ; 1\rangle\rangle \text {; } \\
& c_{3}=\langle\langle 8 ; 0.5\rangle,\langle 1 ; 1\rangle\rangle \text {; } \\
& c_{4}=\langle\langle 2 ; 1\rangle,\langle 4 ; 0.5\rangle,\langle 2 ; 1\rangle,\langle 1 ; 1\rangle\rangle \text {; } \\
& c_{5}=\langle\langle 2 ; 1\rangle,\langle 5 ; 0.5\rangle,\langle 2 ; 1\rangle,\langle 1 ; 1\rangle\rangle \text {; } \\
& c_{6}=\langle\langle 2 ; 1\rangle,\langle 2 ; 1\rangle,\langle 1 ; 1\rangle\rangle \text {. }
\end{aligned}
$$


Kolejnym elementem, który wymaga zdefiniowania, jest struktura świadomości każdego gracza. Zgodnie z ogólnym modelem w tym celu należy zbudować dla każdego z graczy macierz o wymiarach $n \times$ x określającą ich świadomość. Przykładowa macierz dla gracza pierwszego zostanie zaprezentowana poniżej.

$$
A_{1}=\left[\begin{array}{cccccc}
67 & 42 & 16 & 28 & 17 & 10 \\
- & 42 & - & - & - & - \\
- & - & 16 & - & - & - \\
- & - & - & 28 & - & - \\
- & - & - & - & 17 & - \\
- & - & - & - & - & 10
\end{array}\right]
$$

Element $a_{11}=67$ należy rozumieć jako wybór gracza pierwszego, element $a_{12}$ jako wybór gracza drugiego z perspektywy gracza pierwszego. Natomiast elementy $a_{22}=42$ lub $a_{33}=22$ obrazują, jak gracz pierwszy wyobraża sobie wybór gracza drugiego oraz trzeciego. Z macierzy można także odczytać, że gracz pierwszy nie jest świadomy oceny wyborów przeciwników przez innych graczy. Macierze reprezentujące strukturę kolejnych graczy są budowane w analogiczny sposób. Oczywiście macierz świadomości może zostać zmodyfikowana w procesie operacji informacyjnej. Ostatnim elementem składającym się na model gry jest refleksyjny podział zbioru graczy, który opisuje subiektywną ocenę poziomów refleksji przeciwników danego gracza. Należy także założyć maksymalny poziom refleksji graczy, który w tym wypadku będzie równy $m=5$. Macierz przedstawiająca refleksyjny podział zbioru z perspektywy gracza pierwszego przedstawia się następująco.

$$
\aleph_{1}=\left[\begin{array}{llllll}
5 & 2 & 1 & 4 & 3 & 0 \\
1 & 2 & 1 & 0 & 1 & 0 \\
0 & 0 & 1 & 0 & 0 & 0 \\
1 & 2 & 3 & 4 & 2 & 4 \\
2 & 0 & 2 & 1 & 3 & 1 \\
0 & 0 & 0 & 0 & 0 & 0
\end{array}\right]
$$

Zgodnie z założeniami dany gracz uważa, że jego przeciwnicy są na poziomie refleksji co najmniej o jeden niższym niż jego własny poziom refleksji. Dlatego też na podstawie subiektywnej oceny gracz może wydedukować możliwą wersję ocen poziomów refleksji swoich przeciwników o innych graczach. Ten sposób pozwala na przedstawienie, jak dany gracz ocenia innych graczy $a_{12}=1, a_{13}=1$, oraz postrzeganie poziomów refleksji przez innych, np. ocena poziomu refleksji gracza trzeciego przez gracza drugiego z perspektywy gracza pierwszego $a_{23}=1$.

\section{Wnioski}

Techniki wojny informacyjnej oraz operacji informacyjnych, jakkolwiek inaczej nazywane, były znane już w starożytnych Chinach, imperium mongolskim czy Macedonii rządzonej przez Aleksandra Wielkiego. Charakter wojen informacyjnych oraz operacji informacyjnych będzie nadal ściśle zależał od rozwoju nauki oraz technologii. 
Ten temat jest zagadnieniem interdyscyplinarnym oraz wieloaspektowym, co dodatkowo komplikuje jego skuteczną analizę.

Badania nad tym zjawiskiem są niezbędne w celu jego poznania, późniejszej identyfikacji oraz opracowania metod przeciwdziałania. Niniejszy artykuł jest próbą modelowego podejścia do opisu zjawiska, jakim jest wojna informacyjna. Główne założenie zostało zrealizowane przez zbudowanie modelu operacji informacyjnych.

Zaproponowany w pracy model macierzowych gier refleksyjnych jest połączeniem teorii gier, teorii sterowania refleksyjnego, refleksji informacyjnej oraz strategicznej. Pozwala na szczegółowy opis elementów niezbędnych do przedstawienia procesu operacji informacyjnych. Użyteczność modelu została zweryfikowana przez jego użycie do opisu gry p-Beauty Contest Game.

W literaturze przedmiotu istnieje wiele opisów jakościowych. Opis ilościowy $\mathrm{w}$ postaci modelu macierzowych gier refleksyjnych oraz zastosowanie technik symulacji pozwalają jednak na łatwiejsze rozpoznanie wszelkich aspektów składających się na zjawisko operacji informacyjnych.

\section{Bibliografia}

Kasprzyk R., Diffusion in Networks, „Journal of Telecommunications and Information Technology" 2012, nr 2, s. 99-106.

Kasprzyk R., Modele ewolucji systemów złożonych i metody badania ich charakterystyk dla potrzeb komputerowej identyfikacji potencjalnych sytuacji kryzysowych, 2012 r., Wojskowa Akademia Techniczna, praca doktorska.

Kasprzyk R., The Essence of Reflexive Control and Diffusion of Information in the Context of Information Environment Security, w: Internetional Conference in Intelligent Systems in Production Engineering, and Maintenance. ISPEM 2018. Advances in Intelligent Systems and Computing, t. 835, A. Burduk i in. (red.), Cham 2018, Springer, s. 720-728.

Lefebvre V.A., Sketch of Reflexive Game Theory, Irvine 1998, University of California School of Social Sciences.

Mazur M., Jakościowa teoria informacji, Warszawa 1970, Wydawnictwa Naukowo-Techniczne.

Mazur M., Cybernetyczna teoria układów samodzielnych, Warszawa 1966, Państwowe Wydawnictwo Naukowe.

Mikhailov A.P, Marevtseva N.A., Models of Information Warfare, „Mathematical Models and Computer Simulations" 2012, nr 3, s. 251-259.

Nowacki G., Współczesne poglądy na prowadzenie walki informacyjnej. Studium teoretyczne, Warszawa 2001, Akademia Obrony Narodowej. 
Novikov D.A., Chkhartishvili A.G., Mathematical Models of Informational and Strategic Reflexion: a Survey, „Advances in Systems Science and Application” 2014, nr 3, s. 254-278.

S. Skeath, J.A. Livingston, A Step Ahead? Experienced Play in the p-Beauty Game, https://ssrn. com/abstract $=1680542$.

Słownik języka polskiego, https://sjp.pwn.pl/szukaj/refleksja.html [dostęp: 8 IV 2019].

Watson J., Wprowadzenie do teorii gier, Warszawa 2011, Wolters Kluwer Polska.

Wojnowski M., „Zarzadzanie refleksyjne” jako paradygmat rosyjskich operacji informacyjno-psychologicznych w XXI w., „Przegląd Bezpieczeństwa Wewnętrznego” 2015, nr 12, http:// cejsh.icm.edu.pl/cejsh/element/bwmeta1.element.desklight-ee571f3e-2942-46ce-9e19-af8e970c6f7a [dostęp: 30 III 2019].

\begin{abstract}
Abstrakt
Współczesne społeczeństwa są często określane mianem społeczeństw informacyjnych. Dzięki rozwojowi sieci Internet praktycznie każda osoba na kuli ziemskiej może zdobyć potrzebne informacje. Ta możliwość jest zarazem wadą i zaletą. Informacja jest coraz częściej traktowana jako kolejny rodzaj broni, który może zostać wykorzystany do realizacji określonych celów. Jednak już od dawna posługiwano się nią w celach militarnych oraz politycznych przez dezinformację, propagandę czy prowadzenie wywiadu. Rozwój technologii nadał konfliktowi informacyjnemu jedynie inną formę. Działania wchodzące w skład operacji informacyjnych są ukierunkowane na wywarcie wpływu przez podmiot sterujący na podmiot sterowany, w celu wykonania przez niego czynności wcześniej założonej przez podmiot sterujący. Celem tego rodzaju konfliktów nie jest przejęcie danego terytorium, skupiają się one na świadomości danego społeczeństwa. Dlatego też należy się zastanowić nad sposobami oraz możliwościami modelowania oraz symulacji sytuacji strategicznych z niepełną wiedzą, jakimi są operacje informacyjne. Jedno $\mathrm{z}$ podejść do modelowania operacji informacyjnych jest opisane $\mathrm{w}$ teorii sterowania refleksyjnego, która opisuje również techniki ich prowadzenia. W artykule przedstawiono koncept sterowania refleksyjnego oraz model zbudowany na jego podstawie.
\end{abstract}

Słowa kluczowe: operacje informacyjne, sterowanie refleksyjne, modelowanie operacji informacyjnych. 


\title{
Information operation modeling using reflexive control theory
}

\begin{abstract}
Modern societies are often referred to as information societies. Thanks to the development of the Internet, virtually every person on the globe can get the information they need. This possibility is both a disadvantage and an advantage. Information is increasingly used as another kind of weapon that can be used to achieve specific goals. However, it has long been used for military and political purposes through disinformation, propaganda and intelligence. The development of technology has only given information conflict a different form. Actions involved in information operations are aimed at exerting influence by the controlling entity on the controlled entity in order to perform an action previously assumed by the controlling entity. The purpose of this type of conflict is not to take over a given territory; they focus on the consciousness of a given society. Hence, it is necessary to consider the ways and possibilities of modeling and simulating strategic situations with incomplete knowledge, which are information operations. One of the approaches to modeling information operations is constituted by the theory of reflexive control, which at the same time describes the techniques of conducting them. The article presents the concept of reflexive control and the model built on its basis.
\end{abstract}

Keywords: information operations, reflexive control, information operation modeling. 